\title{
Numbers and Chronicles: Close Relatives 2
}

In 2008 I published an article entitled "Numbers and Chronicles: Close Relatives"1, where I showed that the two books share much in common in their content, but often take quite different approaches. I briefly presented nine topics: 1. The relationship between priests and Levites; 2 . Pesach; 3. The tithe; 4. Temple financing; 5. The registration of the people; 6 . No collective liability; 7. Holy war; 8. Agriculture; and 9. Narrative. My aim in the present contribution is to clarify three of these points: numbers 1 (priests and Levites), 5 (registration) and 7 (holy war); four additional issues will also be examined.

\section{The (Two) Silver Trumpets}

According to Numbers 10:1-2, ${ }^{2}$ Yahweh gives Moses the order to make two silver trumpets of "hammered work" (שתי חצוצרת כסף מקשה). They serve to summon the congregation and signal for its departure. When the Israelites begin a war in

1 Hans-Peter Mathys, "Numeri und Chronik: nahe Verwandte," in The Books of Leviticus and Numbers, ed. Thomas Römer, BETL 215 (Leuven: Peters, 2008), 555-78. In his article "Numbers and Chronicles: False Friends or Close Relatives?” Hebrew Bible and Ancient Israel [HeBAI] 8 (2019): 332-77, Louis Jonker alludes to the title of my contribution. The publication of Jonker's essay overlapped with the preparation of the present contribution. I maintain the substance of my remarks as they were presented at the Lausanne conference. Regarding the dating of Chronicles, Jonker formulates almost apodictically (p. 339): "There is general agreement that the book of Chronicles also originated in the late Persian era, towards the end of the Achaemenid rule, in the first half or around the middle of the fourth century B.C.E." Later on, he somewhat softens this judgement. Note however that such a dating is by no means uncontested; see Hans-Peter Mathys, "Chronikbücher und hellenistischer Zeitgeist," in Hans-Peter Mathys, Vom Anfang und vom Ende. Fünf alttestamentliche Studien, BEAT 47 (Frankfurt a.M.: Lang, 2000), 41-155 for dating Chronicles to the early Hellenistic period. Georg Steins, Die Chronik als kanonisches Abschlussphänomen. Studien zur Entstehung und Theologie von 1 / 2 Chronik, BBB 93 (Weinheim: Beltz Athenäum 1995) proposes an even later date (in the Maccabean period); see also Israel Finkelstein, Hasmonean Realities Behind Ezra, Nehemiah, and Chronicles, Ancient Israel and Its Literature 34 (Atlanta: SBL Press, 2018). For the general assumptions underlying the present contribution, see my first paper on the topic.

2 Sir 50:16 refers to this chapter: "Then the sons of Aaron shouted; they blew their trumpets of hammered metal; they sounded a mighty fanfare as a reminder before the Most High."

Hans-Peter Mathys, University of Basel 
the land, they are to give its signal by sounding the trumpets. However, the instrument is also used for ritual occasions (Num 10:10): ${ }^{3}$

Also on your days of rejoicing, at your appointed festivals, and at the beginnings of your months, you shall blow the trumpets over your burnt offering and over your sacrifices of well being ...

The following sentence makes clear the importance of these trumpets, which are reserved for the priests (Num 10:8):

The sons of Aaron, the priests, shall blow the trumpets; this shall be a perpetual institution for you throughout your generations.

The second-most frequent occurrence of the noun, after Numbers 10, is found in Chronicles. The trumpets are sounded after Jehoshaphat's successful war against the Moabites and Ammonites (2 Chr 20:28):

They came to Jerusalem, with harps and lyres and trumpets, to the house of Yhwh.

However, the trumpets are much more frequently used for cultic and cult-adjacent occasions. Their importance is shown by the fact that the priests are responsible for playing the instrument, not the Levites. Two examples: When the Ark is brought up to Jerusalem for the second time, priests mentioned by name play the trumpet before the Ark (1 Chr 16:6).

A fine example of the trumpet's use in the cult can be found in the description of the Passover held under King Hezekiah (2 Chr 29:27-28):

Then Hezekiah commanded that the burnt offering be offered on the altar. When the burnt offering began, the song to Yhwh began also, and the trumpets, accompanied by the instruments of King David of Israel. The whole assembly worshiped, the singers sang, and the trumpeters sounded; all this continued until the burnt offering was finished.

The trumpet has replaced the שפפָר as the signal instrument and has also partly replaced it in cultic practice. Although there are also two passages in Kings (1 Kgs 11:14 [2x]; 12:14), one in Hosea (Hos 5:8) and one in the Psalter (Ps 98:6) that mention the trumpets, the use of חָצוֹצוּרת is nevertheless clearly concentrated in post-exilic texts, in Numbers ${ }^{4}$ as well as Chronicles. ${ }^{5}$ In addition, the noun is

3 Translation of biblical passages according to NRSV.

4 Num 10:2, 8, 9, 10; 31:6. The bulk of the attestations are concentrated in one chapter.

51 Chr 13:8; 15:24, 28; 16:6, 42; 2 Chr 5:12, 13; 13:12, 14; 15:14; 20:28; 23:13; 29:26-28. 
attested in both Ezra (3:10) and Nehemiah (12:35, 41). I do not rule out the possibility that trumpets were used early in Israel and that the horn was used in post-exilic times. I would simply like to indicate that on the literary level, the trumpet appears almost exclusively in late texts, and that to a certain extent, this should be interpreted as an indication of the trumpet gaining importance in the cult of the Second Temple - as did temple music and singing in general. ${ }^{6} 1-2$ Kings offer little in this respect, and the laws of Exodus, Leviticus and Numbers contain only one single provision concerning temple music. According to Chronicles, in the absence of Mosaic laws, temple music and singing are regulated by King David (1 Chr 16).

The importance of the two trumpets in the Second and Herodian temples is also made clear by coinage as well as the Arch of Titus in Rome, which depicts the Romans carrying off loot from the temple of Jerusalem. Among the spoils shown on the Arch are two trumpets alongside the seven-branched menorah and the tables of the bread of the presence. ${ }^{7}$

Here, questions arise concerning the trumpets of whether the Chronicler consciously took up Numbers 10 and whether he would have also incorporated the trumpets into his work had Numbers 10 and Numbers 31:6 not yet existed. The first possibility is supported by the fact that in Chronicles, the trumpets actually find use on occasion, while Numbers 10 merely envisages them being played. There are four occasions for which Numbers stipulates sounding the trumpets: 1) gathering the congregation; 2) setting up the camp; 3) signaling war; and 4) various ritual occasions, including days of rejoicing. Interestingly, the trumpets in the book of Numbers do not resound when the people (are summoned and) depart throughout their desert march (though perhaps the text takes this for granted). Since the Chronicler omits the entire march through the desert in his work, the trumpets cannot resound at all on this occasion. They do so for the first time at the Ark's transfer to Jerusalem. Yet the configuration of the orchestra accompanying them in this procession differs between 2 Samuel 6:5 and 1 Chronicles 13:8: In 2 Samuel 6:5, various juniper woods are used, i. e. wind instruments, while the

6 For a general overview see Hans Seidel, Musik in Altisrael, BEATAJ 12 (Frankfurt a.M.: Lang, 1989); Joachim Braun, Die Musikkultur Altisraels/Palästinas. Studien zu archäologischen, schriftlichen und vergleichenden Quellen, ОВО 164 (Freiburg i.Ü.: Universitätsverlag, 1999).

7 Whether the two instruments depicted upon the Arch of Titus in Rome are actually the two trumpets of Num 10 has proven controversial. They could instead be the tuba sacrum known in Rome. This thesis is seemingly supported by the fact that the menorah on the Arch does not correspond to the lampstand as represented in the Old Testament; see Lars Maskow, Tora in der Chronik. Studien zur Rezeption des Pentateuchs in den Chronikbüchern, FRLANT 274 (Göttingen: Vandenhoeck \& Ruprecht, 2019), 376 and literature cited. 
orchestra of the Chronicler also includes his beloved singers as well as the trumpets, which do not replace the ram horns like elsewhere. According to Maskow, the Chronicler introduced the trumpets in this passage because he saw a parallel between the march through the desert and the procession of the Ark. ${ }^{8}$ This is a daring interpretation. In the second, successful attempt to transfer the Ark, seven (!) priests are named who blow the trumpet (1 Chr 15:24; without parallel in 2 Samuel 6), in the final act of which the Chronicler again uses an impressive orchestra (v. 28: shouting, horns, trumpets, cymbals, harps, and lyres), while the original in Samuel is content with shouting and horns (2 Sam 6:15). One gets the impression that the Chronicler mentions almost all of the instruments of an orchestra from his time period.

Trumpets resound in two wars: that of Abijah against Jeroboam (2 Chr 13:12, 14), and that of Jehoshaphat against a Transjordanian coalition ( 2 Chr 20:28). In the former case, only the trumpet is used, played by priests according to v. 14. In 2 Chronicles 20:28, the trumpets are merely one of several instruments. After their victory, the Judeans return to Jerusalem accompanied by an orchestra; before the hostilities, only the singers were in action.

The remaining passages concern the cult. The dedication of the Jerusalem temple is a crucial event in the Chronicler's history of the cult. At the end of the ceremony, the priests proceeded out of the sanctuary, while the Levites, who were singers and their brothers, stood east of the altar with cymbals and harps and lyres, and with them a hundred and twenty priests blowing trumpets; trumpeters and singers "sang with one voice" (2 Chr 5:12-13). When renewing the covenant with God under King Asa (2 Chr 15), the congregation swore to Yhwh with a loud voice and with rejoicing and with trumpets and horns (v. 14). It is irrelevant here who plays which instrument; the Chronicler may implicitly assume that the trumpets were reserved for priests.

The end of Athaliah's illegitimate rule is framed musically. She watches as the king stands on a pedestal, "and the trumpeters beside the king, and all the people of the land rejoicing and blowing trumpets, and the singers with their musical instruments leading in the celebration" (2 Chr 23:13-14). The people playing instruments reserved for priests in this passage is astonishing and should not be dismissed by the flippant idea that they acted in exuberance of emotions.

Of course, the Passover celebration under King Hezekiah is framed musically as well (2 Chr 29). However, very different statements follow each other in the report of this event: Hezekiah stations the Levites in the house of Yhwh with cymbals, harps and lyres (v. 25); the Levites stand in line bearing the instruments

8 Maskow, Tora in der Chronik, 373. 
of David, while the priests wield the trumpets (v. 26); at the burnt offering, the singing and trumpeting begins, alongside the instruments of David (v. 27); the only performers are the singers and the trumpeters (v. 28).

What a confusing picture! No two passages correspond with one another. The result is best explained as follows: In his work, the Chronicler depicted the cultic realities of his time, while at the same time sketching an ideal image of it. The ideal element clearly dominates in the war reports, which are strongly cultic in tone.

The preceding observations have important consequences for the assessment of the relationship between Numbers 10 and the book of Chronicles. An evaluation of this relationship cannot be made without taking into account the cultic realities from the time of the Chronicler, which are difficult to assess, and there are few sources available other than Numbers 10 and Chronicles themselves. The most important of these are the three attestations of the "trumpet" in Ezra and Nehemiah and the almost complete absence of the instrument in the Deuteronomistic literature, the only attestations being 2 Kings 11:14 (2x); 12:14. The only conclusion that can be drawn from this is certainly what has already been established, namely that the trumpet played a much more important role in (late) postexilic times than in the time of the Temple of Solomon. Numbers 10 and Chronicles adopt this reality in different ways: The author of Numbers 10 considers what role the trumpet might have played with the Israelites before they conquered the land they were promised and before they built the temple in Jerusalem. The feasts to be celebrated in the future and the use of the trumpet in war could only be addressed in general terms. The most concrete and precise expression of the Chronicler's views on the past is found with the people's departure in the desert: a long time ago, far enough that no one can check whether it constitutes an accurate reflection of the past itself. We do not know why Moses makes only two trumpets at the command of Yhwh. The Chronicler reckons with bigger, but offers different numbers. Even the priestly privilege of blowing the trumpet, established in Numbers 10:8, is not something to which the Chronicler adamantly adheres. This may perhaps reflect a rich cultic reality. However, under no circumstances should the attestations of the trumpets be considered a mere continuation of Numbers 10. This would mean applying the principle of scriptura sui ipsius interpres where it has no place. 


\section{Korah (and Company)}

In 2008, I discussed briefly and very generally the relationship between Levites and priests in the books of Numbers and Chronicles. In the present contribution, I would like to clarify one point, namely the history of the Korahites. The story of Korah and "all his company" in Numbers 16 is well-known. More relevant to the present context, however, is a brief recapitulation of the incident in Numbers 26. It concludes in v. 11 as follows:

Notwithstanding, the sons of Korah did not die.

For the Chronicler, this sentence is of central importance. According to 1 Chronicles 9, which lists the inhabitants of Jerusalem, Levites also lived in the city. Verses 17-20 are particularly revealing:

The gatekeepers were: Shallum, Akkub, Talmon, Ahiman; and their kindred Shallum was the chief, stationed previously in the king's gate on the east side. These were the gatekeepers of the camp of the Levites. Shallum son of Kore, son of Ebiasaph, son of Korah, and his kindred of his ancestral house, the Korahites, were in charge of the work of the service, guardians of the thresholds of the tent, as their ancestors had been in charge of the camp of Yhwh, guardians of the entrance. And Phinehas son of Eleazar was chief over them in former times; Yhwh was with him.

Shallum occupies a crucial position in this section. Numbers does not reveal whether the Korahites could still perform the functions originally assigned to them. The Chronicler's answer to this question is unequivocal: Of course they could! In 1 Chronicles 9:22, the Chronicler also states that a descendant of Shallum by the name of Zechariah was appointed by David and Samuel. He also draws attention to the fact that the family was stationed at the King's Gate in the east of the city and had fulfilled its duties to the Chronicler's own day.

Note that the Korahites in 1 Chronicles 9:19 are called "guards at the thresh-

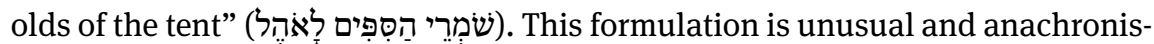
tic. It creates a link from the time of composition to the time of the wanderings in the desert. There is a continuum between these periods: during all this time, the Korahites served as guards at the thresholds of the tent. The prominent position taken by Phinehas in 1 Chronicles 9:20 may be explained by the fact that, according to Numbers 25:7-8, he performed a heroic deed by killing the Israelite man and the Midianite woman who had committed adultery together. 


\section{The Covenant of Salt}

Salt and religion are closely connected. The Old Testament prescribes salt for sacrifices (Lev 2:13; Ezek 43:24). Salt makes food more durable and therefore represents a permanence and inviolability; the term "salt" is therefore very well suited for the characterization of covenants, which are eternally valid by nature and inviolable by claim. ${ }^{9}$ Not only is this close relationship between covenant and salt characteristic of the Old Testament, but, as Wellhausen points out, it is also attested among Arab tribes. ${ }^{10}$ In this regard, the Arabic term milcha "covenant" speaks for itself. ${ }^{11}$

In the Old Testament, the term "covenant of salt" is first used in Numbers 18, a chapter which regulates the maintenance of priests. Verse 19 reads as follows:

All the holy offerings that the Israelites present to Yhwh I have given to you, together with your sons and daughters, as a perpetual due; it is a covenant of salt forever (מלחק עולם ברית (מלח עולם before Yhwh for you and your descendants as well).

The claims of the priests and their families are thus safeguarded. In this passage, note, besides the "covenant of salt," the two attestations of עiֹ לים reinforcing the aspect of duration.

The Chronicler introduces the notion of a "covenant of salt" where one would not necessarily expect it: 2 Chronicles 13:5, concerning Abijah, the successor to King Rehoboam:

Do you not know that Yhwh God of Israel gave the kingship over Israel forever to David and

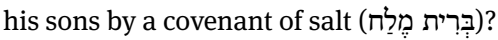

There is no doubt that the Chronicler, strongly departing from his Deuteronomistic source, was inspired by Numbers 18:19. Japhet's interpretation is nearly correct: "The parallelism is clear: a divine grant (holy offerings//kingship) to a favoured beneficiary (Aaron//David) sealed by an eternal commitment."12 Interestingly, the Chronicler, while adopting the term "salt covenant", omits the term "eternal." This is all the more surprising since "eternal covenant" is attested quite often in

9 Jonker, "Numbers and Chronicles," 349-50.

10 Julius Wellhausen, Reste arabischen Heidentums (Berlin: De Gruyter, $\left.{ }^{3} 1961\right), 186$.

11 Hans Wehr, Arabisches Wörterbuch für die Schriftsprache der Gegenwart. Arabisch-Deutsch (Wiesbaden: Otto Harrassowitz, ${ }^{51985)}, 1219$.

12 Sara Japhet, I \& II Chronicles. A Commentary, The Old Testament Library (London: SCM Press, 1993), 691. 
the Old Testament. ${ }^{13}$ This "quote" weighs all the more heavily since the indirect parallelization of Aaron and David constitutes striking and unexpected evidence of the importance that the Chronicler bestows upon the priests. It is not by chance that the Chronicler uses the term "covenant of salt" and not "eternal covenant" in this passage. He thereby underpins Abijah's claim to reign over the northern and southern kingdoms, which form but one realm.

\section{Artificial Proper Names}

Artificial proper names can be found in many parts of the Old Testament, and this is true of Numbers and Chronicles to a remarkable extent. ${ }^{14}$ This can be counted as another point that they share in common with one another, as they each contain whole groups of artificial names. In Numbers, see the list of tribal princes (Num 1), names containing El and Shaddai as theophoric elements: Eliab, Eljasaph, Elizur, Elishama, Gamliel, Deuel, Nethanel, Pagiel, Shelumiel, Ammi-shaddai, Zurishaddai, Shedeur. How can this be explained? In my opinion, Ziemer has provided the right answer to this question by pointing to a principle of the final composition, that there were no names of persons containing the theophoric element Yhwh in pre-Mosaic times. ${ }^{15}$

The example from Chronicles is even more spectacular. In 1 Chronicles 25:4, there is a series of ten (!) proper names of temple singers which, read one after the other, constitute a short psalmic prayer:

Be gracious to me, O Yhwh (חנניה), be gracious to me (חניה), (אליאתה), I

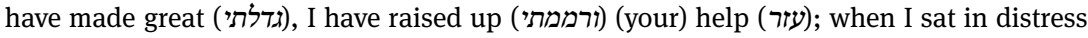
(ישבקשה), I said (מלותי): Give abundance (הותיר) of manifestations (מרזיר).

Some of these proper names belong to the common Hebrew onomasticon, such as חנניה, while others do not belong to it at all, such as מלותי "I have spoken." Incidentally, this passage is a variation of the proverb "nomen est omen": "Tell me your name, and I'll tell you what you do."

13 Gen 9:16; 17:7, 13, 19; Ex 31:16; Lev 24:8; Num 18:19; (25:13); 2 Sam 23:5; Isa 24:5; 55:3; 61:8; Jer 32:40; 50:5; Ezek 16:60; 37:26; Ps 105:10; 1 Chr 16:17.

14 Hans-Peter Mathys, "Künstliche Personennamen im Alten Testament,” in “... der seine Lust hat am Wort des Herrn!“. Festschrift für Ernst Jenni, ed. Jürg Luchsinger, Hans-Peter Mathys and Markus Saur, AOAT 336 (Münster: Ugarit-Verlag, 2007), 218-49. The proper names mentioned and treated below are listed in alphabetical order in this paper.

15 Benjamin Ziemer, Abram - Abraham. Kompositionsgeschichtliche Untersuchungen zu Genesis 14, 15 und 17, BZAW 350 (Berlin: De Gruyter, 2005), 322-23. 
As another example, Numbers 11 reports how Moses takes the spirit that rests on him and lays it on the seventy men, the elders. The story then continues as follows (vv. 26-30):

Two men remained in the camp, one named Eldad, and the other named Medad, and the spirit rested on them; they were among those registered, but they had not gone out to the tent, and so they prophesied in the camp. And a young man ran and told Moses, "Eldad and Medad are prophesying in the camp." And Joshua son of Nun, the assistant of Moses, one of his chosen men, said, "My lord Moses, stop them!” But Moses said to him, "Are you jealous for my sake? Would that all Yhwh's people were prophets, and that Yhwh would put his spirit on them!” And Moses and the elders of Israel returned to the camp.

The point here is not the content of this story, although it is highly interesting. We are only interested in the two men, Eldad and Medad. Their names, which rhyme, are probably formed from the root ידד "love". ${ }^{16}$ Yet this does not matter to us either. Rather, the two men serve the same function; they keep apart from the seventy, and in their similarity, they therefore also bear similar, almost identical names.

Let us turn to the parallel example in Chronicles. ${ }^{17}$ According to 2 Kings 12:2122, King Joash died at the hands of two conspirators. According to the Masoretic Text, their names are "Jozabad" and "Jehozabad," but on the authority of many Hebrew manuscripts, the Septuagint, Vulgate and Targum Jonathan, "Jozabad" should probably read "Jozacar." The Chronicler has appropriated this story, but calls the first conspirator "Zabad" rather than "Jozacar" (2 Chr 24:26), so that the two murderers each have a name formed from the same root, זבד: "Zabad" and "Jehozabad." Since they are involved in the same action, they must also be called similarly. However, the change of name is also facilitated by the fact that and $\supset$ are very similar in appearance. BHS suggests reading the first name as Jozacar with reference to the parallel in 2 Kings 12 and the translations (reckoning with a haplography). The Chronicler's theology speaks against this emendation.

16 Cf. Johann Jakob Stamm, Beiträge zur hebräischen und altorientalischen Namenkunde, ed. Ernst Jenni and Martin A. Klopfenstein, OBO 30 (Freiburg i.Ü.: Universitätsverlag, 1980), 26-7, 38. 17 On this example, see Hans-Peter Mathys, "Philologia sacra: das Beispiel der Chronibücher," ThZ 53 (1997): 67. 


\section{War, Looting, and Spoils of War}

The Old Testament relates countless wars, from local skirmishes to the "World War" of Gen 14 as well as fantastic depictions such as that of Josh 6, the conquest of Jericho. In many wars, the victors take spoils, either for the temple or for the warriors, and occasionally for both. The spoils may be large or small, containing merely a single item or a much wider range of loot. The actual war is waged only by men, but women and children may also appear in connection with these conflicts. Last but not least, it is important to distinguish between ordinary wars and those resembling a worship service; the latter can also be associated with elements of the "war of Yhwh." In reviewing every important war in the Old Testament, two emerge, each with a specific profile, that are very closely related but stand very much on their own: the Israelites' war against the Midianites in Numbers 31 and the war that Jehoshaphat waged against a Transjordanian coalition (2 Chr 20). ${ }^{18}$ Closest to these two texts comes the conquest of Jericho, as described in Josh 6 . Note that this observation should help to further liberate this text from its "Deuteronomistic captivity" than has been done so far. I would like to draw the attention to two similarities and one important difference.

Both campaigns are religious undertakings. The expression "holy war," as I described these wars in my first publication on the subject, is perhaps infelicitous, since it falls a little short of the mark. In the campaign against the Midianites, the priests Phinehas and Eleazar perform important functions; the army goes to war with holy instruments and trumpets. In Jehoshaphat's war against the Transjordanian coalition, the Levites - i. e. the Kohathites and the Korahites, much appreciated by the Chronicler - have an important task: to praise Yhwh with song, harp, lyre and trumpet.

In no other wars are the spoils so large. The Chronicler's description of the loot is rather general (2 Chr 20:25):

When Jehoshaphat and his people came to take the booty from them, they found livestock in great numbers, goods, clothing, and precious things, which they took for themselves until they could carry no more. They spent three days taking the booty, because of its abundance.

Numbers 31:32, on the other hand, gives a list: 675,000 flock animals, 72,000 cattle (approximately $5 \%$ of today's Swiss cattle livestock!) and 61,000 donkeys. The spoils are distributed among the warriors, the rest of the congregation, and the temple. 2 Chronicles 20 contains no information about distribution, but to assume

18 See Jonker, “Numbers and Chronicles,” 367-8. 
that the temple did not receive part of it is as daring as to assume that the soldiers themselves did not receive any share. The motif of important spoils is, by the way, very widespread in Chronicles as a whole.

It is not only men who are present when Jehoshaphat preaches his sermon on war. The Chronicler explicitly states (2 Chr 20:13):

Meanwhile all Judah stood before Yhwh, with their little ones, their wives, and their children.

In Numbers 31, the latter are not explicitly mentioned, but they are implicitly present in v. 3 (note the term "men"):

So Moses said to the people, "Arm some of your men for the war, so that they may go against Midian, to execute Yhwh's vengeance on Midian."

However, there is also an important difference between the two texts concerning the role of God in these conflicts: In Numbers 31, though the initiative for war is taken by Yhwh, many of the usual elements of the "holy war" are missing. In 2 Chronicles 20, however, Jehoshaphat must wage a defensive war; it contains elements of the "war of Yhwh," such as an invitation to the warriors not to be afraid, and the promise of divine assistance (v. 20). In Numbers 31, the Israelites themselves wage war and kill their enemies; in 2 Chronicles 20, Yhwh does so indirectly by setting an ambush and allowing the enemies to kill each other.

\section{Families, Women, Daughters, and Questions Related to Heritage}

More than the other books of the Old Testament, Numbers and Chronicles take a great interest in families, especially women and daughters, not only in individual persons. The Sondergut of Numbers contains six texts dealing with women: First, there is Numbers 5:11-31, the jealousy offering by which a woman must prove that she has not committed adultery; then Numbers 30, a chapter that regulates the vows of men briefly and those of women very extensively; I will handle neither the strange story of the pierced Midianite woman (Num 25) nor Miriam and Aaron's jealousy of Moses (Num 12). The best-known texts dealing with women are Numbers 27:1-11 and Numbers 36, both of which regulate the hereditary rights of daughters in the event of no male offspring or the premature death of one.

I will also treat neither the jealousy sacrifice nor the story in Numbers 12 in the present article. However, let me make a few brief remarks about the 
vows: ${ }^{19}$ Among other things, Numbers 30 provides the circumstances under which a father/husband can invalidate the vow of his daughter/wife. Whether these provisions are misogynous or, to the contrary, women-friendly is a matter of controversy, and opinions are divided even on what Numbers 30 says about the position of women. After all, women can make vows without first having to ask the respective male authorities, whether a father or husband. Widows and women rejected by their husbands must stand for their own vows. The position of these women, however, is not as dire as it would seem at first sight. Levine even contends that Numbers 30 expresses misgivings about the overly strong entrepreneurial freedom of women. ${ }^{20}$ Nevertheless, we are left only to speculate about the specific background of Numbers 30. For example, certain scholars believe that women were fascinated and attracted by religious foundations, and that the men responsible for them would therefore have been required to "foot the bill" as legal householders. ${ }^{21}$ Whatever the case may be, vows made by women seem to have been of considerable importance: They are still addressed at considerable length in the Talmud..$^{22}$ Thus, vows may have played a far more important role in the (religious) life of the Israelites than the Old Testament texts would suggest.

In Chronicles, women and children (especially daughters) also play an important role outside the genealogical lists. These texts often include detailed genealogical information on Judean kings from the Chronicler's Sondergut, namely Rehoboam, Abijah, Jehoshaphat and perhaps also Joash. The information is most precise concerning Rehoboam (2 Chr 11:18-23). According to the Chronicler, Rehoboam had two wives, Mahalath and Maacah, with the latter being his preferred wife. With the two of them in addition to sixteen other wives and sixty concubines, he fathered a total of 28 sons and 60 daughters; we only know the names of Mahalath's and Maacah's children. Rehoboam arranged his succession in such a way that he appointed Abijah, the firstborn of Maacah, heir to the throne and politically quashed his other sons by appointing them as governors and by generously endowing them with food and women. The information on Mahalath and Maacah seems credible, but the large number of Rehoboam's wives (eighteen) and even more the round number of his concubines and daughters - sixty each - seems less so. Commentators evaluate this section in completely different

19 On this text see, e. g., Horst Seebass, Numeri. 3. Teilband Numeri 22,2 - 36,13, BK IV/3 (Neukirchen-Vluyn: Neukirchener Verlag, 2007), 265-82 (with extensive bibliography).

20 Baruch A. Levine, Numbers 21-36. A New Translation with Introduction and Commentary, AB 4A (New York: Doubleday, 2000), 436.

21 See Levine, Numbers 21-36, 436: “Or, was there an increase in religiosity affecting women ...?” 22 See Talmudic tractate Nedarim. 
ways. According to Japhet, women and children are "signs of God's blessing."23 Rudolph, who considers the verses to be an addition by a later author, ${ }^{24}$ sees Rehoboam's "Haremswirtschaft" 25 presented here as serving as an example for Rehoboam's apostasy against Yahweh. In the text, however, there is no such criticism. The question then arises of why this insertion happens in Chronicles but not in Kings, as well as the even more fundamental question of why it happens at all. It is particularly astonishing how soberly the passage assesses the king's "Realpolitik," which its author qualifies as "wise." The information is so precise that one supposes a specific contemporary historical situation to stand behind it, though such a situation is impossible to identify.

The Chronicler's information about King Abijah is less precise (2 Chr 13:21). After coming to power, he reportedly took fourteen wives and conceived twenty-two sons and sixteen daughters with them. Although this information, written in typical Chronistic style, does not mention any names, it is generally regarded as trustworthy. ${ }^{26}$

As with Rehoboam, the information about Jehoram also concerns the succession to the throne. The Chronicler first relates Jehoram's accession, and then lists the other five sons of Jehoshaphat, to whom he gives many gifts - together with

23 Japhet, I \& II Chronicles, 663.

24 Wilhelm Rudolph, Chronikbücher, HAT 1. R. 21 (Tübingen: Mohr Siebeck, 1955), 233; cf. Martin Noth, Überlieferungsgeschichtliche Studien. Die sammelnden und bearbeitenden Geschichtswerke im Alten Testament (Tübingen: Max Niemeyer, ${ }^{31967), ~ 143, ~ n . ~ 1: ~ " d i e ~ i n ~ d i e s e n ~ A b s c h n i t t e n ~}$ vorkommenden Namen gehören, soweit sie nicht aus der alten Überlieferung stammen, zum nachexilischen Typ".

25 Rudolph, Chronikbücher, 233.

26 See Rudolph, Chronikbücher, 239: "Der Schwächung Jerobeams entspricht die Erstarkung Abias (21); zu den Zeichen des göttlichen Segens rechnet der Chr. auch seine große Kinderzahl, deren Geschichtlichkeit nicht zu bezweifeln ist; daß ihm alle Kinder nicht erst während seiner dreijährigen Regierungszeit geboren wurden, liegt auf der Hand, die gegenteilige Meinung (Wellhausen, Prol. 216) gehört einer Zeit an, wo man dem Chr. jede Dummheit zutraute.” Japhet, I \& II Chronicles, 699, also assumes that the Chronicler may have had sources unavailable to the author of the Deuteronomistic History. Although she admits that "the passage reflects Chronistic idiom ... and conforms to the Chronicler's view that children are a sign of blessing, these are hardly sufficient reason to doubt the information itself. The similar accounts for Rehoboam (II Chron. 11.18-21) and Jehoshaphat (II Chron. 21.2-4) indicate that systematic family records were kept for all the Davidic kings (except Asa) who reigned before the major crisis in the days of Athaliah. One wonders whether the Chronicler had access to a source with this genealogical information, which the Deuteronomistic author of Kings simply ignored, or whether these were fragmentary records which somehow survived to the Chronicler's time.” These are all very daring assumptions - even if Chronicles is dated very early. 
fortified cities in Judah. Yet Jehoram does not seem to trust his brethren and kills them all (2 Chr 21:3-4). In vv. 1-4, only sons and brothers play a role:

Jehoshaphat slept with his ancestors and was buried with his ancestors in the city of David; his son Jehoram succeeded him. He had brothers, the sons of Jehoshaphat: Azariah, Jehiel, Zechariah, Azariahu, Michael, and Shephatiah; all these were the sons of King Jehoshaphat of Judah. Their father gave them many gifts, of silver, gold, and valuable possessions, together with fortified cities in Judah; but he gave the kingdom to Jehoram, because he was the firstborn. When Jehoram had ascended the throne of his father and was established, he put all his brothers to the sword, and also some of the officials of Israel.

The historicity and accuracy of this information is hardly disputed by the commentators, though there may well be cause for doubt. ${ }^{27}$ Jehoram's brothers are likely called "sons of Jehoshaphat" because they are only half-brothers to the future king. King Jehoshaphat acts sensibly in giving rich gifts to the brothers of the future ruler; he probably seeks to prevent them from striving for the throne themselves. However, Jehoram distrusts his brothers and subsequently kills them.

Finally, attention must be drawn to 2 Chronicles 24:3; the verse belongs to the Sondergut:

Jehoiada got two wives for him / himself (לל), and he became the father of sons and daughters.

It is not quite clear whether is refers to the priest Jehoiada or King Joash - grammatically, both translations are possible. However, in agreement with Japhet, the second possibility appears more likely. On the one hand, the verse emphasizes Jehoiada's strong commitment to the king while on the other hand making clear how much the Chronicler is concerned about the king's family. The information is so general that even Japhet does not exclude the possibility "that these biographical data are the Chronicler's own surmises."28

If this startling information about Rehoboam and Jehoram is correct, why has only the Chronicler included such in his work? Did the confusion surrounding the succession of Alexander the Great ${ }^{29}$ raise the specter of similar events in Judah's past?

27 For example, compare the simultaneous occurrence of the two personal names עַזְרָיָהוּ.

28 Japhet, I \& II Chronicles, 841.

29 See e. g. The Cambridge Ancient History. Volume VII. Part I The Hellenistic World, ed. Frank W. Walbank, A.E. Astin, M.W. Frederiksen and R.M. Ogilvie (Cambridge: Cambridge University Press 21984), 23-61 (Chapter 2: The Succession to Alexander, Edouard Will). 
The passages handled immediately above, especially the references to large numbers of descendants, do not restrict themselves to royal lineages, as shown by 1 Chronicles 25:5:

All these were the sons of Heman the king's seer, according to the promise of God to exalt him; for God had given Heman fourteen sons and three daughters.

Although the daughters are not mentioned by name, it is notable that they are mentioned at all. It is difficult to find a specific reason for this. The explanation most often advanced may be correct, that "the intention is simply to emphasise the blessing of Heman's family." 30 This interpretation is all the more probable as Job, after his restitution, is also blessed with seven sons and three daughters (Job 42:13). We will return to this passage below.

Numbers and Chronicles contain further texts in which women play a special role. These texts are of particular interest in cases where they interpret preexistent texts. As one case, Budd and Kellermann have shown that Numbers 5:5-10 is "some kind of halakhic comment on Lev 5." 31 Only here are men and women named separately (Num 5:5-6):

Yhwh spoke to Moses, saying: Speak to the Israelites: When a man or a woman wrongs another, breaking faith with Yhwh, that person incurs guilt.

A similar case is found in Deut 23:22 and Numbers 6:1, as the juxtaposition of the two texts shows:

\section{Deut 23:22}

If you make a vow to Yhwh your God, do not postpone fulfilling it; for Yhwh your God will surely require it of you, and you would incur guilt.

Numbers 6:1-2

Yhwh spoke to Moses, saying: Speak to the Israelites and say to them: When either men or women make a special vow, the vow of a nazirite, to separate themselves to Yhwh,

Numbers addresses the remuneration of a priest's family members (including women!) more often than the book of Leviticus does, with the latter not being particularly helpful in this respect. Leviticus contains only scattered information on this subject (see, e.g. Lev 2:3; 7:6, 14; 22:7). In contrast, Deuteronomy contains

30 Hugh G. M. Williamson, 1 and 2 Chronicles, NCB (Grand Rapids: Wm.B. Eerdmans, 1982), 168. 31 Philip J. Budd, Numbers, WBC 5 (Waco: Word Books Publisher, 1984), 57; cf. Diether Kellermann, Die Priesterschrift von Numeri 1,1 bis 10,10 literarkritisch und traditionsgeschichtlich untersucht, BZAW 120 (Berlin: De Gruyter, 1970), 66-69. 
more provisions, and - particularly important - a full, coherent section: Deut 18:1-8. However, even more extensive is Numbers 18. In the present context, it is particularly important that the sons and daughters of the clergy are also mentioned (Num 18:11, 19):

\begin{abstract}
${ }^{11}$ This also is yours: I have given to you, together with your sons and daughters, as a perpetual due, whatever is set aside from the gifts of all the elevation offerings of the Israelites; everyone who is clean in your house may eat them.

${ }^{19} \mathrm{All}$ the holy offerings that the Israelites present to Yhwh I have given to you, together with your sons and daughters, as a perpetual due; it is a covenant of salt forever before Yhwh for you and your descendants as well.
\end{abstract}

The inclusion of sons and daughters is all the more remarkable, as it "[n]icht [um] die Versorgung der Priester, sondern [um] die Heiligkeit der ihnen zufallenden Opferanteile [geht]". ${ }^{32}$ Milgrom defines the social and economic background of v. 11 as follows:

daughters that are with you: The implication is that married daughters who have joined their lay husband's households are not eligible to partake of sacred food (see Lev 22:12-13). All other members of the priest's household, including his slaves (Lev 22:11) - but not his hired laborers since they maintain their own household (Lev 22:10) - may also share his sacred food. ${ }^{33}$

After victorious efforts in battle, the question always arises of how to divide the spoils. The basis provision can be found in Deut 20:13-14:

(...) and when Yhwh your God gives it into your hand, you shall put all its males to the sword. You may, however, take as your booty the women, the children, livestock, and everything else in the town, all its spoil. You may enjoy the spoil of your enemies, which Yhwh your God has given you.

The Israelites adhere to these regulations in the war against the Ishmaelites, during which they act as follows (Num 31:9-12):

The Israelites took the women of Midian and their little ones captive; and they took all their cattle, their flocks, and all their goods as booty. All their towns where they had settled, and all their encampments, they burned, but they took all the spoil and all the booty, both

32 Horst Seebass, Numeri. 2. Teilband Numeri 10,11 - 22,1, BK IV/2 (Neukirchen-Vluyn: Neukirchener Verlag, 2003), 221.

33 Jacob Milgrom, The JPS Torah Commentary. Numbers במדבר (Philadelphia: The Jewish Publication Society, 1990), 151. 
people and animals. Then they brought the captives and the booty and the spoil to Moses, to Eleazar the priest, and to the congregation of the Israelites, at the camp on the plains of Moab by the Jordan at Jericho.

Most striking in this passage is the level of detail with which the spoils are listed. However, some verses later, a correction of the provision of Deut 20:13-14 is made when Moses criticizes the Israelites for having spared the women (Num 31:15-16). It is precisely they who, at the behest of Balaam, had made the Israelites fall away from Yhwh in Peor. He calls on the Israelites to kill all the boys, and then also every woman who has already consorted with a man. Only the virgins are to be spared..$^{34}$

On the whole, it is astonishing how much attention women are given in the book of Numbers, both as individual figures as well as the collective of Israelite women. The same holds true for the book of Chronicles, though only a few examples must suffice to show this: 1) It is only 1 Chronicles 2:16-17 that enables determining the exact kinship of Zeruiah. The other passages where she is mentioned do not make perfectly clear that she is a sister of David. 2) Only 1 Chronicles 2:26 knows of Atarah, the second wife of Jerahmeel. 3) The following sentence is found in two passages - with almost identical wording (1 Chr 8:29; 9:35):

Jeiel the father of Gibeon lived in Gibeon, and the name of his wife was Maacah.

Maacah is not mentioned anywhere else, and no commentators say anything about the presence of Maacah in this verse. 4) 1 Chronicles 25:5 is a particularly remarkable passage:

All these were the sons of Heman the king's seer, according to the promise of God to exalt him; for God had given Heman fourteen sons and three daughters.

5) Finally, we should also mention the passages from the Sondergut of the Chronicler, where women (and children) are explicitly included in the congregation of the Israelites. As part of a covenant renewal during the reign of King Asa, the Israelites pledge (2 Chr 15:12-13):

(...) to seek Yhwh, the God of their ancestors, with all their heart and with all their soul. Whoever would not seek Yhwh, the God of Israel, should be put to death, whether young or old, man or woman (למן קטן ועד גדול למאיש ועד אשה).

34 This is exactly what happens; see v. 35. 
The speech of Azariah, in which this passage is found, occurs in a literary vacuum of sorts. The fact that women and children are also punished for violating the covenant is a significant "upgrade" in status for them.

War is basically a matter for men, and the exceptions confirm this rule. These include, to a certain extent, the war against the Transjordanian coalition (2 Chr 20). In the assembly of Judah and Jerusalem, Jehoshaphat offers a prayer of supplication to God (vv. 5-12). The report of the Chronicler continues as follows (v. 13):

Meanwhile all Judah stood before Yhwh, with their little ones, their wives, and their children (גם טפם נשיהם ובניהם).

One might also translate it as "even their little ones ...”. Yet they play no role throughout the remaining course of events, much less a major role. They appear on stage for a short time because families are important to the Chronicler. For a moment, he forgets that the text is about a war and addresses the community gathered in the temple precinct.

A crux interpretum in 1 Chronicles 21:20 is the king hiding with his four sons. It could be a misspelling of "and when he saw him", ${ }^{35}$ though this is anything but certain. Could it be that even in this passage, the Chronicler is thinking of the family, one of his favorite subjects?

The two laws regarding Zelophehad's daughters, Numbers 27:1-11 and Numbers 36 are two of the most well-known texts in Numbers. In the present context, I cannot deal with the controversial interpretation of these two chapters, even less so with the details of interpretation. However, I would like to show how infertility, and more precisely the absence of male heirs, connects the books of Numbers and Chronicles.

Although numerous Old Testament stories concern the absence of a male heir, they usually end positively, as is particularly clear in the stories of the patriarchs and in 1 Samuel 1-2. However, matters are different in Numbers and Chronicles.

Numbers 26:33 reports that Zelophehad had only daughters and no sons, and mentions the daughters by name. The Sondergut of Chronicles contains some passages reporting absences of male offspring; the author also briefly discusses the case of Zelophehad. The passages read as follows:

$1 \mathrm{Chr} 2: 30$

The sons of Nadab: Seled and Appaim; and Seled died childless (לא בנים).

$1 \mathrm{Chr}$ 2:32

The sons of Jada, Shammai's brother: Jether and Jonathan; and Jether died childless (לא בנים).

35 See commentaries. 


\section{Chr 2:34-35}

Now Sheshan had no sons, only daughters (ולא היה לששן בנים כי אם בנות); but Sheshan had an Egyptian slave, whose name was Jarha. So Sheshan gave his daughter in marriage to his slave Jarha; and she bore him Attai.

1 Chr 7:15

And Machir took a wife for Huppim and for Shuppim. The name of his sister was Maacah. And the name of the second was Zelophehad; and Zelophehad had daughters (ותהינה לצלפחד בנות).

$1 \mathrm{Chr}$ 23:22

Eleazar died having no sons, but only daughters (ולא היו לו בנים כי אם בנות); their kindred, the sons of Kish, married them.

1 Chr 24:2.

But Nadab and Abihu died before their father, and had no sons (ובנים לא היו להם); so Eleazar and Ithamar became the priests.

This passage recapitulates Numbers 3:4:

Nadab and Abihu died before Yhwh when they offered unholy fire before Yhwh in the wilderness of Sinai, and they had no children (ובנים לא היו להם). Eleazar and Ithamar served as priests in the lifetime of their father Aaron.

Let us look briefly beyond these two books. Josh 17 reports how the claims of Zelophehad's daughters, who invoke Yhwh's command, are fulfilled. The text quite clearly and extensively engages Numbers 27:1-11; 36, a further indication of how crucial the subject of a missing male heir was at a certain period. In some aspects, Josh 17 can be regarded as the "Vollendung" 36 , or rather the "second Vollendung" of the Torah. Only after reading this text do we discover how the claims of Zelophehad's daughters are finally realized.

This likewise applies to the establishment of asylum cities. Though there are three laws governing the asylum procedure, it is Josh 20 in its Masoretic version that makes perfectly clear how this procedure works. ${ }^{37}$ In other words, Josh 20 answers the questions that remain unanswered following Exod 21:12-14; Deut 19 and Numbers 35.

A second digression: The issue of daughters and their right to inherit also plays a role in the book of Job, which probably dates to the Achaemenid period. At the very beginning of the book, its author states that Job has seven sons and three

36 See Reinhard Achenbach, Die Vollendung der Tora. Studien zur Redaktionsgeschichte des Numeribuches im Kontext von Hexateuch und Pentateuch, BZAR 3 (Wiesbaden: Harrassowitz, 2003).

37 See Hans-Peter Mathys, "Homizid und nicht Asyl / Asylstädte. Das Thema von Numeri 35,934," ThZ 76 (2020): 122-3. 
daughters (Job 1:2); he is a blessed man! The same number of sons and daughters are given to him after his recovery (Job 42:13). Note that these numbers of Job's descendants are reminiscent of the fourteen sons and three daughters of Heman (1 Chr 25:5). It is both interesting and irritating that the three daughters of Job receive much more attention than his seven sons. The author of the book of Job goes even further than Numbers 25:1-11 and 36 concerning the inheritance rights of daughters (Job 42:15):

In all the land there were no women so beautiful as Job's daughters; and their father gave them an inheritance along with their brothers.

What is the social and economic background that explains the improved position of daughters and their right to a share of inheritance, whether linked to the absence of a male heir or not? Most interpreters shun this question. One reason for this caution is given by Raik Heckl: "Verblüffend sind die nachfolgenden zwei Verse, deren Intention wahrscheinlich nicht vollständig zu ergründen ist." 38 A remarkable proposal was made by Lipiński, according to whom Job 42:13-15 might reflect the custom whereby a rich father also gave his daughters a share of the inheritance. ${ }^{39}$

Some commentators have pointed out that in the ancient Near East, daughters could sometimes inherit, usually in the absence of a male heir. They refer to parallels from Nuzi, Ugarit, Alalah and Deir el-Medina, ${ }^{40}$ though these parallels call for a certain amount of skepticism due to the large gap in time separating Numbers from these texts. Fohrer considers the frame of Job to be old and thus argues the opposite, that Job 42:15 bears witness to an older practice than that required in the texts of Numbers. ${ }^{41}$ However, this older "Volksbuch" has completely disappeared from scholarly literature on the book of Job. The books of Numbers and Job are quite closely related in their dates; they both belong to the Achaemenid period. Therefore, potential parallels must first and foremost be sought in the fifth and fourth centuries BCE. These can be found in Greece and Sparta. Close (and more

38 Raik Heckl, Hiob - vom Gottesfürchtigen zum Repräsentanten Israels: Studien zur Buchwerdung des Hiobbuches und zu seinen Quellen, FAT 70 (Tübingen: Mohr Siebeck, 2010), 309.

39 Edward Lipiński, Art. נחל, TWAT V (Stuttgart: Kohlhammer, 1986): 348.

40 See, e. g., Kenneth Numfor Ngwa, The Hermeneutics of the 'Happy' Ending in Job 42: 7-17, BZAW 354 (Berlin: De Gruyter, 2005), 114-15. For a theological interpretation of Job 42:13-15, see Jürgen Ebach, "Hiobs Töchter. Zur Lektüre von Hiob 42,13-15 (auch eine Art Brief an Luise Schottroff)," in Jürgen Ebach, Hiobs Post. Gesammelte Aufsätze zum Hiobbuch zu Themen biblischer Theologie und zur Methodik der Exegese (Neukirchen-Vluyn: Neukirchener Verlag, 1995), 67-72.

41 Georg Fohrer, Das Buch Hiob, KAT XVI (Gütersloh: Gütersloher Verlagshaus Gerd Mohn, 1963), 544-45. 
distant) parallels are so numerous and varied that they can only be presented here in extracts and in simplified form. ${ }^{42}$

Before addressing these parallels, some general observations must be noted. Functioning families formed the backbone of a society's prosperity, and this is unlikely to have been very different in ancient Israel. Questions of inheritance are of relatively little importance in the Old Testament. In the everyday life of the Israelites, however, they certainly played a much more prominent role than, for example, capital crimes. In this respect, ancient Greek texts are a better mirror of reality than the Old Testament. This is especially true for one point: The laws were not always followed, as the sources occasionally attest. The fact that the inheritance rights of daughters both in Greece and in the Old Testament occupy an important place has a simple explanation that most commentators of Numbers do not consider worth mentioning: In quite many families, there have been "only" daughters, as the following statistical considerations make clear: If one assumes quite correctly that boys and girls each account for $50 \%$ of births, the following applies: Two-child families have a $25 \%$ chance of having all-male offspring and a $25 \%$ chance of all-female offspring; in three-child families, this number is $12.5 \%$, etc. Zelophehad had five daughters, which corresponds to $3.125 \%$ - much more likely than one would generally assume.

I will now compile and briefly interpret the regulations concerning the hereditary daughters in Greece. It should be noted in advance that, as in Israel, the passing of paternal inheritance to a son was regarded as the normal or ideal case in Greece (understood in the broadest sense of the term). The importance of hereditary daughters is shown by the fact that in Athens, there was a terminus technicus

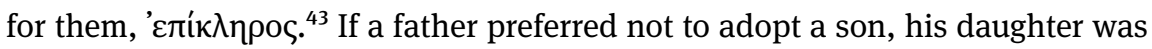
entitled to inherit. We know very little about the hereditary daughters in Sparta. According to Herodotus (VI:57), one of the many privileges of the Spartan king was to appoint a husband for a daughter if her father had not already done so, thus acting as a "surrogate father." ${ }^{4}$ In his criticism of the "Spartan property

42 A selection of relevant books: Alick Robin Walsham Harrison, The Law of Athens: The Family and Property (Oxford: Oxford University Press, 1968), especially 122-62; Stephen C. Todd, The Shape of Athenian Law (Oxford: Clarendon Press, 1993), 228-231; Cynthia B. Patterson, The Family in Greek History (Harvard: Harvard University Press, 1998); Cheryl Anne Cox, Household Interests. Property, Marriage Strategies, and Family Dynamics in Ancient Athens (Princeton: Princeton University Press, 1998; see index: "heiress daughters"); Josine Blok, Citizenship in Classical Athens (Cambridge: Cambridge University Press, 2017).

43 Short information in Gerhard Thür, "Epikleros," Der Neue Pauly 3 (Stuttgart: J. B. Metzler, 1997): 1117-18.

44 Patterson, The Family in Greek History, 101. 
system," Aristotle pointed out that about $40 \%$ of the land was owned by women. As one reason for this, he mentions the high number of ' $\varepsilon \pi i k \lambda \eta \rho o$ (Pol. 1270a).

The Gortyn Code dates to the fifth century BCE as the oldest collection of laws in Europe $\mathrm{e}^{45}$ and contains surprisingly detailed provisions concerning hereditary daughters (IV-VI). See the following in particular: "The patroikos is given in marriage to the oldest brother of her father. If there is no brother, she is given to the brother's son. If there are more than one patroikos or more than one son of the brother, then order of age rules. And the epiballon shall have one patroikos and not more." ${ }^{46}$ The elaborate (and even quite complicated) rules that apply if these principles cannot be implemented need not be addressed here.

It is said that Solon, who tried to stabilize the polis of Athens through the establishment of laws, had already promulgated provisions concerning the epikleroi (Aristotle, Ath. Pol. 9.2). The veracity of this assertion is not necessary to examine here, though it is likely. The most exact "rule on the epikleros" is related by Isaeus, who lived from approximately the end of the fifth to the middle of the fourth centuries BCE and was numbered among the Ten Attic Orators. ${ }^{47}$ His extant speeches unexceptionally deal with inheritance matters, including the validity of wills and the succession of heirs. This rule is as follows: "For we consider that the next-of-kin ought to marry this woman, and that the property ought for the present to belong to the heiress, but that, when there are sons who have completed their second year after puberty, they should have possession of it." 48 The pool of pretenders who were eligible as spouses for the hereditary daughter was much wider in Athens than in Gortyn; it included descendants of the uncle and aunt on the father's side as well as descendants of the uncle and aunt on the mother's side. The Athenians were not particularly interested in passing property only patrilineally. Patrilineality thus only played an important role in the political domain. In passing inheritance, the interests of the $\alpha y x ı \sigma \varepsilon \varepsilon^{\alpha} \alpha$ were paramount, consisting more of a "branching web of relationships rather than a 'line'."49

45 Ronald F. Willetts, The Law of Gortyn, Kadmos Supplement 1 (Berlin: De Gruyter, 1967); Anselm C. Hagedorn, Between Moses and Plato. Individual and Society in Deuteronomy and Ancient Greek Law, FRLANT 204 (Göttingen: Vandenhoeck \& Ruprecht, 2004; text of the code and English translation according to Willetts: 285-99).

46 Patterson, The Family in Greek History, 93.

47 Short information in Michael Weißenberger, “Isaios,” Der Neue Pauly 5 (Stuttgart: J.B. Metzler, 1998): 1115-16.

48 Edward Seymour Forster, Isaeus, with an English Translation, LCL 202 (Cambridge: Harvard University Press, 1983), 475.

49 Patterson, The Family in Greek History, 98. 
Plato's innovative solution need not be presented here. For him, "the preservation of a stable property system is a key concern," ${ }^{50}$ which is most likely to be guaranteed if there is only one male heir (Leg. 924-925).

A comparison between the Greek provisions concerning the hereditary daughters and those of the Old Testament shows interesting similarities and differences: ${ }^{51}$ Numbers $27: 1-11$ does not address the question of who should marry the daughters. This gap is closed by Numbers 36, which states that only a man from a clan of the father's tribe is eligible and not a man from another tribe; otherwise the clan would lose a part of its נְחָלָ. Broadly speaking, Numbers 36 is concerned with specific provisions implementing the general provisions of Numbers 27.

Some questions concerning the daughters of Zelophehad are still unresolved. Four of them bear names that are also documented as names of villages. If Numbers 27 was only about the right of inheritance in families, and especially about the right of daughters to inherit, this amendment would probably not call for five daughters. How the inheritance is divided among them is of little importance. Moreover, Numbers 27:1 offers a detailed genealogy of Zelophehad, which is of no interest for the division of the inheritance. Although his daughters are vocal in their demand, as soon as they receive what they desire, they disappear and the remaining inheritance is arranged in case a man has left no heirs at all. Numbers 27 is best understood as an amendment to an inheritance law in which daughters were left with nothing. In this passage, they (or rather, the representatives of their interests) forcefully impose this new law. This lobbying must have been massive, as the singular structure of Numbers 27 makes clear: The five daughters present their case before Moses, the priest Eleazar, the princes, and the whole congregation - a comprehensive body. However, it is not the congregation who makes the decision as expected, but Yhwh, who authoritatively intervenes on the side of the five daughters (v. 7). This divine intervention seems to end any discussion. In order to reinforce this point further, v. 11 stipulates: "It shall be for the Israelites a statute and ordinance, as Yhwh commanded Moses.” Yet, this decision by Yhwh does not please the Gileadites, and they make clear to Moses and the princes of the tribal chiefs that it must be corrected - by keeping daughters of

50 Patterson, The Family in Greek History, 103.

51 So far, this relationship has only been mentioned in passing; see Hagedorn, Between Moses and Plato, 208, n. 59. Studies comparing Greek and biblical law focus on Deuteronomy; see Hagedorn and Leonhard Burckhardt, "Elemente der Vergleichbarkeit von Gesetzgebung. Deuteronom - Gortyn - XII-Tafelgesetze. Eine Skizze,” in Gesetzgebung in antiken Gesellschaften, ed. Leonhard Burckhardt, Klaus Seybold and Jürgen von Ungern-Sternberg, Beiträge zur Altertumskunde 247 (Berlin: De Gruyter, 2007), 1-65. The gap in research is due to the fact that the book of Numbers has long been a Cinderella in research. 
heirs from marrying members of other tribes; otherwise, there would be a danger that one tribe might lose parts of its inheritance to another tribe. This makes sense to Yhwh; he agrees with the Gileadites. Here, he no longer speaks directly, but through Moses (Num 36:5: “Then Moses commanded the Israelites according to the word of Yhwh, saying, 'The descendants of the tribe of Joseph are right in what they are saying."'). Verse 5 unmistakably references Numbers 27:7; this is made clear by the same unusual formulation:

Num 36:5 כן מטה בני יוסף דברים

Num 27:7 כן בנות צלפחד דברת בנסר ימסר

The two hereditary laws in Numbers 27:1-11 and Numbers 36 do indeed have the divine placet, but they do not ultimately proceed from it. Numbers 36 is further characterized by the fact that the correction of the law in Numbers 27 ultimately receives a rational justification. One could indeed argue that God has assigned the individual tribes their settlement areas - but the author of Numbers 36 does not do this, and accusing him of implicitly doing so would be a bold assertion. Apart from these two chapters, there are no other Old Testament legal texts that have such a strong rational foundation rather than being based primarily on theological/ethical motives.

Numbers 27, 36 and the Greek laws/texts I briefly presented above agree with each other on two additional points: They deal extensively with the succession of heirs in the event that a man dies without any male heirs, and they are characterized by a high degree of regulation. In both areas, it is not only a matter of the interests of the "nuclear" family, but also of smaller and larger political groups. In both chapters, Numbers 27 and 36, the problem of the daughters of Zelophehad is not definitely solved. This only happens in Jos 17:3-6.

\section{7 (High) Numbers}

Another characteristic of the books Numbers and Chronicles is their affinity for numbers, especially high ones. ${ }^{52}$ This, of course, is directly related to their

52 On (high/fantastic/symbolic/incredible) numbers in Chronicles and their explanation, see Jonker, "Numbers and Chronicles," 344-7; Ralph Walter Klein, "How Many in a Thousand," in Graham M. Patrick, Kenneth G. Hoglund, Steven L. Mc Kenzie, ed., The Chronicler as Historian, JSOTSup 238 (Sheffield: Sheffield Academic Press, 1997), 270-82; Gary N. Knoppers, I Chronicles 10-29, AB 12 A (New York: Doubleday, 2004), 569-71 (lit.). According to the most credible thesis, proposed by Braun, Levine, Fouts, Skolnic, Klein, and Heinzerling, “[t]he incredible numbers are a literary convention or a scribal embellishment” (570). 
subject matter, such as censuses as well as religious services and the many sacrifices offered on these occasions. Here too, the two books differ considerably from other Old Testament writings. In order to meet the needs of the present essay, it is sufficient to list only the most important passages to offer brief comments, and if necessary, compare them with other passages.

The book of Numbers opens with a census of the tribes of Israel (with the exception of Levi). As is generally recognized, these numbers are fantastic and greatly exaggerated, clearly shown by the total alone: 603,550 (v. 46). The second chapter contains the same figures, though presented here according to the locations of the individual tribes within the camp. Chapter 3 lists the figures for the Levites, who were excluded from the general census. Chapter 4, describing the service of the Levites, also contains information on the number of those who were mustered. The gifts offered by the princes of the tribes (Num 7) are identical, but the author of the chapter lists them for each tribe, together with the numbers. There is a remarkable figure contained in Numbers 25:9: 24,000 men who died of a plague because of fornication with Moabite women. Interestingly, there has never been any mention of this plague before. After the plague, a second census of the people is carried out, again documented by precise numbers (Num 26). The report of the vendetta against the Midianites (Num 31) contains an exceptionally high number of figures. Each tribe must muster 1,000 men to go to war against them. In the war, Israel takes a great deal of spoils. Interestingly, God orders the spoils to be counted exactly and decides on its distribution in detail. This is the most precise and longest list of spoils of war in the Old Testament.

Unlike the book of Numbers, Chronicles does not begin with a census, but with genealogies, and thus does not give figures. This changes in 1 Chronicles 5:18-22, a passage which tells of Reuben warring against Transjordanian populations. 44,760 Reubenites go to war against them, taking 50,000 camels, 250,000 sheep, 2,000 donkeys, and 100,000 people. In a certain sense, this is a short edition of Numbers 31 - but without any religious coloring, much less any justification.

While the genealogies at the beginning of Chronicles do not contain any numbers, this changes in 1 Chronicles 7. Japhet explains this by stating that some of the numbers mentioned in this chapter (may have) come from a military census. ${ }^{53}$ Wilhelm Rudolph, however, notes that the numbers do not fit this kind of genealogy. ${ }^{54} 1$ Chronicles 8:40 mentions not only the number of sons and

53 Japhet, I\& II Chronicles, 169.

54 Rudolph, Chronikbücher, 64. 
grandchildren of Ulam (150), ${ }^{55}$ but also explicitly states that he had many sons and grandchildren. 1 Chronicles 9 lists the inhabitants of Jerusalem. For some of the groups living there, the chapter also lists how many members they counted (vv. 6, 9, 13, 22).

The passages in which the Deuteronomistic History and Chronicles run parallel to each other rarely differ in their figures. Many (especially high) numbers are to be found in the Sondergut of the Chronicler. In the present section we will first deal with parallel passages, then with the Chronicler's Sondergut.

When the Chronicler draws on Vorlagen, he typically also maintains the numbers given in them. ${ }^{56}$ After all, numbers cannot be manipulated at will. Deviations from the Vorlage in Chronicles are often easily explained, not infrequently by accidents through the course of the textual transmission. ${ }^{57}$ Some differences, however, require further explanation.

How exactly should the different figures in the census conducted under King David be explained? This can no longer be answered with absolute certainty, and there are some text-critical problems as well. According to 2 Samuel 24:9, there were 800,000 Israelite soldiers able to take up arms, and those of Judah were 500,000. The Chronicler (1 Chr 21:5-6) offers the following total numbers: $1,100,000$ in "all Israel” and 470,000 in Judah. However, according to him, Levi and Benjamin were not counted among the number. He seems to have thought that 800,000 and 500,000 "represented a total of 100,000 for each tribe (twelve tribes, plus the tribe of Levi) ... he may have concluded that the deletion of Levi and Benjamin should reduce the census total by 200,000 men". ${ }^{58}$

55 Gary N. Knoppers, I Chronicles 1-9, AB 12 (New York: Doubleday 2004), 486: "The number is quite low by the Chronicler's standards and pales in comparison with the size of the three Benjaminite phratries $(7: 7,9,11)$. The small number may be compared with some numbers in the list of Ezra 2\|Neh 7.”

56 See the following parallels: 2 Sam 23:18 || 1 Chr 11:20; 2 Sam 18:13 || 1 Chr 18:12; 2 Sam 10:18 || 1 Chr 19:18 (partially differing); 2 Sam 24:15 || 1 Chr 21:14; 2 Sam 12:30 || 1 Chr 20:2; 2 Sam 24:15 || 1 Chr 21:14; 1 Kgs 3:4 || 2 Chr 1:6; 1 Kgs 10:26 || 2 Chr 1:14; 1 Kgs 10:29 || 2 Chr 1:17; 1 Kgs 5:29 || 2 Chr 2:1 (different numbers of overseers; 1 Kgs 5:30); 1 Kgs 5:27-28 || 2 Chr 2:17 (The Chronicler omits the forced labor, which according to him should not exist in Israel); $1 \mathrm{Kgs} \mathrm{8:62-63} \mathrm{||} 2 \mathrm{Chr} 7: 4-6$; $1 \mathrm{Kgs}$ 10:10 || 2 Chr 9:9; 1 Kgs 10:14 || 2 Chr 9:13; 1 Kgs 22:6 || 2 Chr 18:5; 1 Kgs 10:16-17 || 2 Chr 9:15-16 (partially differing); 1 Kgs 12:21 || 2 Chr 11:1.

57 2Sam 23:8 || 1 Chr 11:11; 2 Sam 8:4 || 1 Chr 18:4; 2 Sam 10,6 || 1 Chr 19,6 (It is also possible that the Chronicler makes 32,000 men and 1,000 talents of silver out of 33,000 men); 1 Kgs 7:26 || 2 Chr 4:5 (However, the different figures may also be based on different calculation methods); 1 Kgs 9:23 || 2 Chr 8:10; 1 Kgs 9:28 || 2 Chr 8:18; 1 Kgs 5:6 || 2 Chr 9:25.

58 Knoppers, I Chronicles 10-29, 753. For further explications and details, see also Klein, "How Many in a Thousand?": 275. 
The Chronicler's report on the construction of the temple is very different from its Vorlage; above all, he shortens it considerably, which complicates the comparison between the two versions. The height of the temple according to Chronicles was 120 cubits (approx. 60 meters, 2 Chr 3:4), which seems completely implausible; it is often reduced to 20 cubits (approx. 10 meters) by a text-critical operation. However, the evidence for this correction is meagre. According to 2 Chronicles 3:15, the columns Boaz and Jachin are 35 cubits high, but according to the Vorlage ( $1 \mathrm{Kgs} 7: 15$ ) only 18 cubits, which is more likely to be the case architecturally. The number 35 can be explained as the addition of the three numbers of 1 Kings 7:15-16: $18+12+5$ (Has the Chronicler not correctly understood the construction principle of the two pillars? .... $)^{59}$

The situation is quite different with the Sondergut of the Chronicler, which contains countless exaggerated numbers. These concern, among other things, wars and other conflicts, whether religiously motivated or not. The first example in Chronicles is the conflict between Reuben, Gad and the half-tribe of Manasseh versus a coalition of native Transjordanian peoples (1 Chr 5:18-22). The numbers are abnormally large. The Israelite tribes of the Transjordan lead 44,760 men into battle and capture 50,000 camels, 250,000 sheep, 2,000 donkeys and 100,000 people. Williamson tries to explain the gigantic number of Israelites by comparing them to even larger numbers in Numbers 1 and Numbers $26 .{ }^{60}$ In 1 Chronicles 12:24-39, the numbers of the divisions of the armed troops who came to David in Hebron were 120,000 from the Transjordanian tribes and 340,822 in total muster. According to 1 Chronicles 27:2-15, David led 12 divisions of 24,000 men each, with each serving one month.

"Great enemy, great honor": The enemy may also sometimes dispose of an impressive army. This is the case of Pharaoh Shishak. In the fifth year of King Rehoboam's reign, Shishak went up to Jerusalem with 1,200 chariots, 60,000 horsemen, and countless people (2 Chr 12:3). Even more impressive was the army with which Jeroboam fought against Abijah, who could only muster half as many people for the battle: 800,000 Israelites against 400,000 Judahites. Nevertheless, Judah wins through Yahweh's partiality (2 Chr 13:5). However much the Chronicler appreciates high numbers, they are of no use when Yhwh enters the stage. Yet even if Yhwh's intervention is decisive, the Chronicler does not do without large numbers - not even without the 500,000 Israelites who remain lying dead on the battlefield (v. 17).

59 Cf. Rudolph, Chronikbücher, 204.

60 Williamson, 1 and 2 Chronicles, 66. 
Abijah is the king of numbers par excellence. His army comprises 300,000 Judeans and 280,000 Benjaminites (2 Chr 14:7). In the following verse we are told that an army of the Cushite Serah is advancing against him consisting of no less than 1,100,000 (!) men and 300 chariots. Likewise, a census of the Judeans in the time of Amaziah yields a number of 300,000 warriors in addition to 100,000 Israelite mercenaries (2 Chr 25:5-6).

The cult, too, gives the Chronicler the opportunity to record high numbers. ${ }^{61}$ David alone donates 100,000 kikkar of gold, 1,000,000 kikkar of silver, and much more to the temple (1 Chr 22:14). 1 Chronicles 29 records immense donations made by David and the people to build the temple (1 Chr 29:4-7). 1,000 young bulls, rams, and lambs are offered as burnt offerings at the sacrificial service that follows, along with sacrificial offerings in abundance (1 Chr 29:21). The figures of the sacrifice that Asa offered in the fifteenth year of his reign are significantly lower: 700 cattle, 7,000 sheep (2 Chr 15:11). The most significant sacrificial service ever held in the history of Israel is undoubtedly the one that took place during the dedication of the Temple of Solomon (2 $\mathrm{Chr} 7: 5$ ). Yet the number of animals sacrificed on the occasion of the Passover celebrations under Hezekiah and Josiah is also quite impressive:

\section{Chr 30:24}

For King Hezekiah of Judah gave the assembly a thousand bulls and seven thousand sheep for offerings, and the officials gave the assembly a thousand bulls and ten thousand sheep.

\section{Chr 35:7-9}

Then Josiah contributed to the people, as passover offerings for all that were present, lambs and kids from the flock to the number of thirty thousand, and three thousand bulls; these were from the king's possessions. His officials contributed willingly to the people, to the priests, and to the Levites. Hilkiah, Zechariah, and Jehiel, the chief officers of the house of God, gave to the priests for the passover offerings two thousand six hundred lambs and kids and three hundred bulls.

It is no surprise that the figures for Josiah are significantly higher than those for Hezekiah: the more sacrifices a king makes, the more important he is. As the discussion above should make clear, (high) numbers are most definitely an important issue in the book of Numbers and Chronicles.

In conclusion, it is undisputed that Numbers and Chronicles are closely related in terms of the contents that they address, and there is likewise a consen-

61 The remunerations which Solomon pays the Tyrians for their services in the building of the temple according to $1 \mathrm{Kgs} 2$ and $2 \mathrm{Chr} 2$ are incomparable with each other. In one case, it is a regular payment, while in the other case, it is a one-time payment. 
sus that the positions on certain topics taken by the Chronicler and the authors of Numbers often differ considerably. However, there is also disagreement as to how these similarities should be explained. This article, like my first one on the subject, concentrates on content and, for practical reasons, largely ignores the justifiable questions of whether the similarities can (also) be explained in a literary-critical way - and if so, how they could be explained. We have primarily been concerned with identifying the topics that were of particular, possibly even preoccupying, interest to the authors of Numbers and Chronicles, who do not seem to have been too far temporally removed from each other. The three most important findings of this paper are as follows: Among these issues were certainly those relating to family law, in particular the law of succession of daughters in the absence of male heirs. This question also preoccupied the legislator of Gortyn, who authored his codex at approximately the same time as the authors of Numbers; the absence of male heirs also features prominently in Chronicles. We dare not even express hypotheses accounting for this striking correlation. The fact that women (and families) generally are common subject matter in Numbers and Chronicles can be explained - again in very general terms - by the fact that this also corresponds to some extent to the place they occupied in society at the time when the present texts were written. In any case, the fact that "artificial” proper names are not only well-documented in Numbers and Chronicles, but are sometimes even key elements of their stories, must be explained as being due to the Zeitgeist of their period of composition. The case is different with the trumpets, which are prominently represented in Numbers and Chronicles. It can be debated whether the Chronicler adopted them from Numbers or whether he so variously used them not only out of interest of Numbers 10 , but because he would have introduced them into his work even if they were missing in Numbers or mentioned only in passing. 